\title{
Waste tires and the burning of sugarcane bagasse in the manufacture of concrete pavers (pavers)
}

\section{Resíduos de pneus e da queima do bagaço da cana-de-açúcar na fabricação de blocos de concreto para pavimentação (pavers)}

\author{
S. P. S. ALTOÉ a,b \\ silviasossai@hotmail.com \\ https://orcid.org/0000-0002-4098-4257 \\ A. SALES b \\ almir@ufscar.br \\ https://orcid.org/0000-0002-7766-5364 \\ C. H. MARTINS c \\ chmartins@uem.br

\begin{abstract}
The research developed has the purpose of analyzing the potential utilization of sugarcane bagasse ash and tire residue in the construction of pavers in replacement of the small aggregate, the natural sand. In order to achieve this objective, the methodology adopted includes steps such as: characterization of the residues to be used, preparation of pavers with different contents of partial replacement of small aggregates, determination of the main pavers characteristics (compressive strength, water absorption, abrasion resistance) . The results proved the viability of the substitution, and the optimum content for the manufacturing of the parts is $27 \%$, being $25 \%$ of BCC and $2 \%$ of tires. The contribution of the research is focused on reducing the consumption of natural resources and the correct disposal of the residues studied.
\end{abstract}

Keywords: sugarcane bagasse ash, tires, pavers, recycling, durability.

\section{Resumo}

A pesquisa desenvolvida tem como proposta analisar a potencialidade de utilização da cinza do bagaço da cana-de-açúcar e do resíduo de pneus na confecção de blocos de concreto para pavimentação (pavers) em substituição do agregado miúdo, a areia natural. Para atingir este objetivo a metodologia adotada compreende etapas como: a caracterização dos resíduos a serem utilizados, confecção de pavers com diferentes teores de substituição parcial de agregado miúdo, determinação das principais características pavers (resistência à compressão, absorção de água, resistência à abrasão). Os resultados comprovaram a viabilidade da substituição, sendo que o teor ótimo para a fabricação das peças é de $27 \%$, sendo $25 \%$ de CBC e $2 \%$ de pneus. A contribuição da pesquisa está voltada para redução do consumo dos recursos naturais e a correta disposição dos resíduos estudados.

Palavras-chave: cinza do bagaço da cana-de-açucar,pneus, pavers, reciclagem, durabilidade.

Universidade Tecnológica Federal do Paraná - Campus Apucarana, Coordenação de Engenharia Civil, Maringá, PR, Brasil;

Universidade Federal de São Carlos, Departamento de Engenharia Civil, Programa de Pós-Graduação em Estruturas e Construção Civil, São Carlos, SP, Brasil;

Universidade Federal de Sào Carlos, Departamento de Engenharia Civil, Programa de Pos Maringá, Departamento de Engenharia Civil, Maringá, PR, Brasil.

Received: 19 Aug 2017 • Accepted: 14 Aug 2018 • Available Online: 20 May 2019

This is an open-access article distributed under the terms of the Creative Commons Attribution License 


\section{Introduction}

The various industrial segments seek every day new technologies and management systems that contribute to the increase of production in order to meet a market with high power consumption and increasingly demanding. However, they are the result of this productive behavior: the need for raw materials and the increasing generation of waste, which leads to an indiscriminate but still necessary extraction of natural resources and the generation of waste in a certain way ignored.

The collection of solutions that minimize the impacts generated by this scenario impels those responsible for production to evaluate and analyze differently two extremes of the production chain: the indiscriminate extraction of natural resources and the consequences of uncontrolled production. As a result, the productive sectors seek to apply environmental management practices and strategies that demonstrate their commitment to this new reality, thus adding more value to their products vis-à-vis a society more aware of the need to seek environmental conservation ( ROSA, 2007) ${ }^{[1] .}$

A solution to this question, pointed out by several lines of research, to minimize the damages caused to the environment and simultaneously guarantee the continuity of production is the use of alternative materials and the replacement, total or partial, of the natural resources, through the recycling of waste. According to John (2000) ${ }^{[2]}$ the first and most visible contribution of recycling is the preservation of natural waste. Since if they are replaced by waste it can be said that there will be an extension of the life of the natural reserves and a reduction of the destruction of the landscape, flora and fauna. The construction sector is one of the most promising sectors for the use of waste as a source of raw material. Since residues from the most different origins have been applied successfully in the manufacture of mortars, concretes, sealing elements, among others. This use of waste in construction meets the industry's need to reduce its environmental impacts: it is currently estimated that the construction industry accounts for $20-50 \%$ of the consumption of natural resources extracted from the planet $(\mathrm{JOHN}, 2000)^{[2]}$.

In Brazil, the approach to waste management was not addressed clearly and directly in Brazilian environmental legislation, and it was implicit and generic until 2010 when Law No. 12,305, called the National Solid Waste Policy (PNRS $)^{[3]}$, regulated by Federal Decree No. 7.404, of December 23, 2010.

The PNRS aims to monitor the waste generated in industrial production processes and their integrated management, and among its principles are shared responsibility for the product life cycle and the recognition of reusable and recyclable solid waste as an economic good and of social, generating value of work and income and promoter of citizenship.

In this way, it is considered that the industries are not only responsible for the waste generated, but also for their products until the final disposal, which should have an environmentally correct destination. The production process must be seen as a whole and integrated into society, in such a way that the reuse of the waste or its recycling must be defined at the beginning of production.

The proposal presented by this work is the reuse of two residues through the partial substitution of the sand used in the making of pavers, which may contribute to a decrease in the extraction of this material, thus avoiding the degradation of the local ecosystem due to the silting caused during the process. For this, the research aims to study the reuse of ash from sugarcane bagasse and the residue of waste tires in the construction of pavers, replacing the small aggregate.

Both the ash from sugarcane bagasse and the waste from waste tires are waste generated annually in large quantities, which has slow decomposition time, and which normally occupy a large volume in landfills, or are improperly dumped and in an indiscriminate way in the environment, which probably has contaminated the soil, air and water, besides posing serious risks to the health of the population.

According to the National Association of Pneumatic Industries (ANIP, 2016) ${ }^{[4]}$ the production of new tires in the year 2015 was 71.9 million units, of this total $63.5 \%$ had the purpose of replacement, that is, about 45 million tires were only changed in 2015 in the country. According to ANIP, of that amount, $46.8 \%$ are used tires that can be returned to the market to be used in vehicles or undergoing some type of refurbishment, and $53.2 \%$ are waste tires, which are no longer used. Since 1999, when manufacturers began collecting tires, by the end of 2014, more than 3 million tonnes of waste tires, equivalent to 625 million tires, were properly collected and destined. The most common form of disposal of waste tires is as an alternative fuel for the cement industry, followed by the manufacture of granulated and powdered rubber for use in rubber or rubber asphalt, shoe soles, fluvial pipelines. However, the industry still says that there is a need for new applications for this material, since the volume of waste generated annually is high and many units are not yet destined for the 824 collection points in Brazil.

In the process of processing sugarcane, the largest by-product generated is sugarcane bagasse, used in large scale as fuel in boilers for power generation that generates two types of ash: heavy ash and fly ash. Taking into account that of the 2016/2017 harvest with an amount of 690.98 million tons of sugarcane (CONAB, 2016) ${ }^{[5]}$, and that all the bagasse would be used as an energy source would then be , produced approximately 4 million tons of ash per year. Approximately 378 million tons of aggregates are used annually in concrete manufacturing. The substitution of this aggregate by the recycled waste in addition to contributing to the reduction of the extraction of the natural resources in large quantities, also, can collaborate to the reduction of $\mathrm{CO}_{2}$ during the transport of the same until the place of use.

In order to analyze the potentiality of the use of the proposed residues, pavers with different substitution levels were tested, which were tested according to current standards, analyzing characteristics such as: resistance, water absorption and abrasion, thus defining the optimal substitution content of the proposed waste.

The methodology used, as well as the definitions used in this work are based on the methodology and results obtained in the work of Altoé $(2013)^{[6]}$, where trait combinations were analyzed and the first studies on the mechanical resistance, absorption and abrasion of concrete blocks for paving.

This work aims to study the use of ash from sugarcane bagasse $(\mathrm{CBC})$ and the residue of waste tires in the replacement of small aggregates for the construction of pavers that are subject to light loads. In order to reach the main objective of this research, the following specific objectives were defined: to analyze the ash characteristics of the sugarcane bagasse and the waste of waste tires in terms of the possibility of its application as a small aggregate; to analyze the influence of the partial replacement of the small aggregate by the proposed residues on the compressive strength, water absorption 


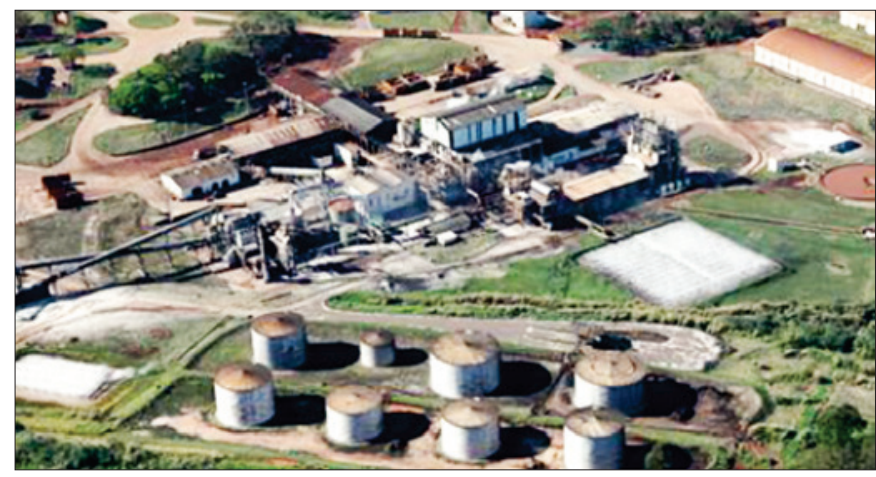

Figure 1

Usaçucar Iguatemi Unit

Source: Usaçucar (2015)

and abrasion resistance of the pavers; to determine the best optimum substitution contents from the interpretation of the data obtained in the different tests performed with the pavers.

\section{Materials and experimental program}

\subsection{Materials}

\subsubsection{Aglomerant}

The cement used in this research was the CP V ARI, once more used by pavers manufacturers. The $C P \vee A R I$ is regulated by ABNT NBR 5733: 1991, and is recommended for the preparation of mortars and concretes that achieve high strength with higher speed $(A B C P, 2002)^{[7]}$, and is widely used in the precast industry

\subsubsection{Large aggregate}

The natural aggregate used in the confection of the blocks was zero gravel, of basaltic origin, commercially known as Pedrisco, with a diameter of between 4.8 and $9.5 \mathrm{~mm}$. The characterization of the sand used in the preparation of the pavers was carried out according to the following standards: determination of the granulometric composition (NBR NM 248: 2003) ${ }^{[8]}$; determination of the unit mass (NBR NM 045: 2006) ${ }^{[9]}$; determination of the specific mass (NBR NM 53: 2009) ${ }^{[10] .}$

\subsubsection{Small aggregate}

The natural aggregate used was the quartz sand. The characterization of the sand used in the preparation of the pavers was carried out according to the following standards: determination of the granulometric composition (NBR NM 248: 2003) ${ }^{\text {[8] }}$; determination of the unit mass (NBR NM $045)^{[9]}$, determination of the specific mass (NBR NM 52: 2009) ${ }^{[11] .}$

\subsubsection{Additive}

In all the molded traces the liquid additive was used for low cement consumption in semi-dry concretes. The characteristics of this additive are shown in Table 1.

\subsubsection{Sugarcane bagasse ash}

The sugarcane bagasse ash used in the research comes from the thermoelectric plant of Santa Terezinha (Usaçucar) Plant, located in the Iguatemi district, approximately $10 \mathrm{~km}$ from Maringá-PR. Figure 2 (A) Crude $\mathrm{CBC}$, (B) Material removed from the $\mathrm{CBC}$ and (C) ) Gray sifted. $\mathrm{BCC}$ was characterized according to the assays described below: - Poz-

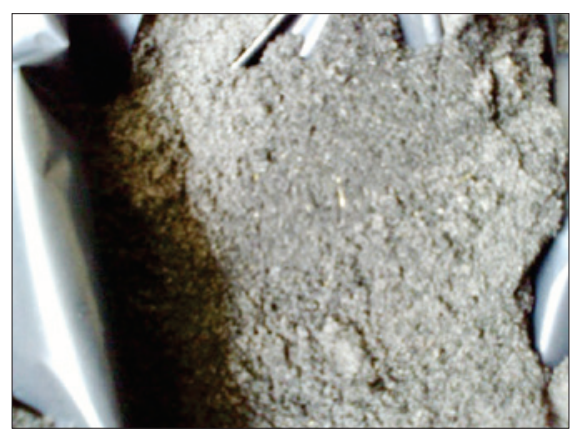

(A)

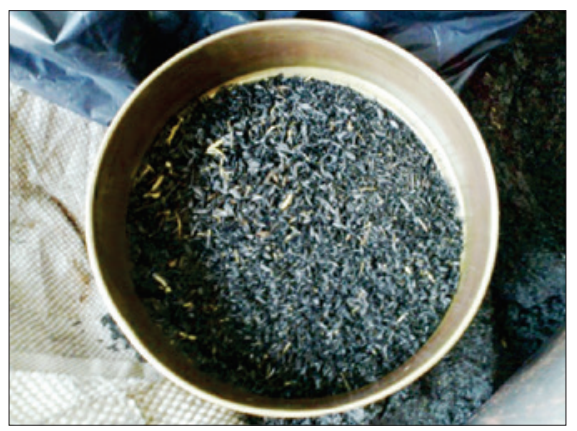

(B)

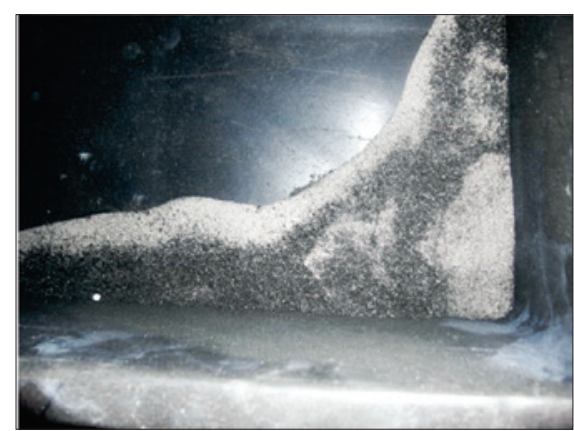

(C)

Figure 2

CBC sample visual aspect: (A) CBC in the crude state; (B) Material removal da CBC; (C) Sieved CBC

Table 1

Additive characteristics

\begin{tabular}{|c|c|c|c|c|c|c|c|}
\hline Manufacturer & Name & Type & State & Color & Density & $\mathrm{Ph}$ & Consumption \\
\hline Sika Brasil & $\begin{array}{c}\text { SikaPaver } \\
\text { HC-10 }\end{array}$ & $\begin{array}{c}\text { Plasticizer type } \\
\text { for concrete } \\
\text { semi liquid } \\
\text { state }\end{array}$ & Liquid & Red & $\begin{array}{c}1.01+0.02 \\
\mathrm{~kg} / \mathrm{l}\end{array}$ & $7+1$ & $\begin{array}{l}0.2 \text { a } 0.5 \% \text { in } \\
\text { relation to the } \\
\text { weight } \\
\text { of cement }\end{array}$ \\
\hline
\end{tabular}

Source: Manufacturer, 2016 


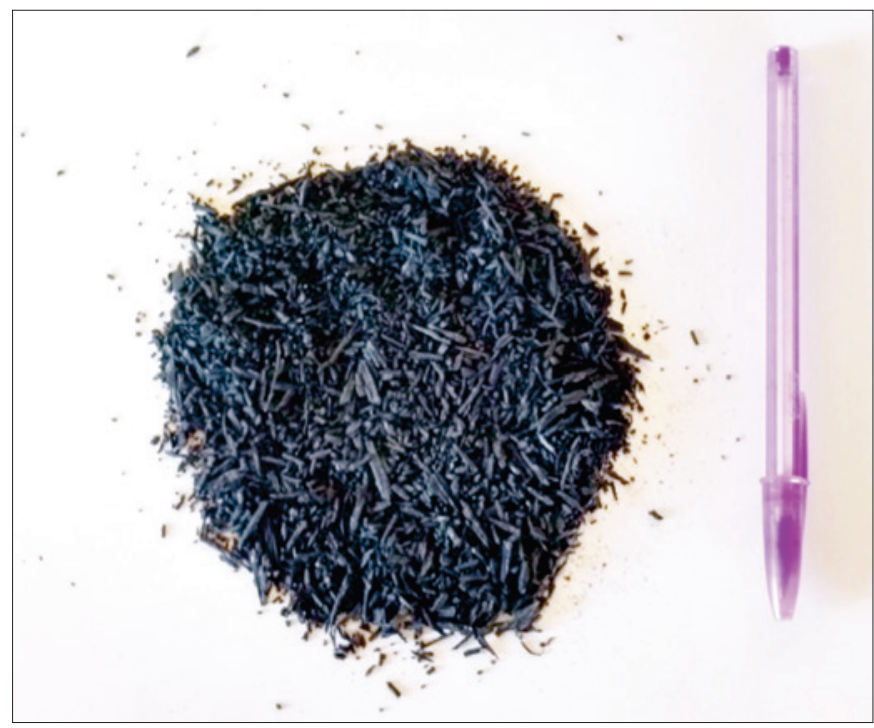

Figure 3

Tire residue

zolanic Activity - The pozzolanic activity was determined by the Modified Chapelle Method, following NBR 15895: 2010 (Pozolanic Materials - Determination of the fixed calcium hydroxide content - Modified Chapelle Method) ${ }^{[12]}$, by the Construction Materials Laboratory of the IPT-SPGranulometric analysis - The determination of the granulometric analysis of the BCC was done by means of sedimentation and sieving, following NBR 7181: 1984 (Soil - Particle size analysis) ${ }^{[13]}$, thus obtaining the grain size curve of the material. - Specific mass: The specific mass of the CBC, being an extremely fine material, should be determined by NBR 6508: 1984 (Soil grains passing through the $4.8 \mathrm{~mm}$ sieve) [14] The procedure used to obtain leachate extract for BCC followed NBR 10005: 2004 (ABNT: 2004) ${ }^{[15]}$, as well as the solubilization procedure followed 10006: 2004 (ABNT: 2004) ${ }^{[16]}$. The samples of leachate and solubilized were subjected to determination of the contaminant contents listed in annexes F and G of NBR 10004: 2004 (ABNT: 2004) ${ }^{[17]}$, by means of Atomic Absorption Spectrometer (AAS) 52 Varian - SPECTRAA-240FS and Ion Chromatograph, Metrohm - 850 Professional IC.

\subsubsection{Residual tire}

The tire residue used in the research was provided by the company Borrachas SS, located in the city of Maringá, which receives waste from tire retread companies throughout the region and is used to manufacture conveyor belts. This residue goes through a process of separation, grinding and sieving, where the rubber is separated from the other components of the tires. After passing through this process, the residue, already in the form of powder, is heated and takes the form of the regenerated rubber, later applied in the manufacture of the belts. After the sample was collected, a sieving was performed in order to remove larger pieces of rubber that were not retained in the sieves of the company equipment. Figure 3 shows the sample after sieving. The tire residues were characterized according to the tests described below:

- Particle size analysis: The tire residue samples were initially dried at room temperature for a period of 72 hours, thus ensuring that the sample was dry for the characterization tests. The granulo- metric composition was determined according to NBR NM 248: 2003 (ABNT: 2003) ${ }^{[8]}$, thus ensuring that the residue corresponds to the characteristics of small aggregate, since the proposal of the study is the substitution of this aggregate;

- Unitary Mass - The test was performed according to NBR NM 45: 2006 (ABNT: 2006) ${ }^{[9]}$, used for aggregates with characteristic dimensions below $37.5 \mathrm{~mm}$;

- Specific mass - As a thin residue, as the CBC, the specific mass should be determined by NBR 6508: 1984 - Soil grains passing through the sieve of $4.8 \mathrm{~mm}$ - Determination of specific mass (ABNT, 1984) ${ }^{[14]}$;

- Leaching and solubilization tests - The procedure used to obtain the leachate extract for BCC followed NBR 10005: 2004 (ABNT: 2004) [15], as well as the solubilization procedure followed 10006: 2004 (ABNT: 2004 ) ${ }^{[16]}$. The samples of leachate and solubilized were subjected to determination of the contaminant contents listed in annexes F and G of NBR 10004: 2004 (ABNT: 2004) ${ }^{[17]}$, by means of Atomic Absorption Spectrometer (AAS) 52 Varian - SPECTRAA-240FS and Ion Chromatograph, Metrohm - 850 Professional IC.

\subsection{Dosage, molding and testing of paving blocks}

\subsubsection{Dosage and molding}

In order to meet the requirements of NBR 9781: 2013 (ABNT: 2013) ${ }^{[18]}$, the ratio between binder and aggregate was defined as 1: 4 , with $55 \%$ of the aggregate used being small aggregate and $45 \%$ according to the trait developed by Amadei $\left.(2011)^{[19}\right]$, trait is validated by the method proposed by Fernandes (2012) ${ }^{[20]}$ and indicated by the ABCP. This methodology systematically presents the dosing procedures, which allows reproducibility in the laboratory, besides being suggested by a representative body.

After defining the dosage to be used in the manufacture of the pavers, the traits were defined, based on the results obtained in the Altoé research (2013) ${ }^{[6]}$. In this research, traces with different levels of substitution, both $\mathrm{CBC}$ and tire, were analyzed, delimiting traces with maximum and minimum levels of substitution of each residue used in the 2013 survey, seeking the highest possible use of the residue in substitution to the natural child aggregate. Table 2 shows the substitution levels of each trace. A fixed a / c ratio of 0.42 , as defined by Altoé (2013) ${ }^{[6]}$, was adopted, and there was no need for

\section{Table 2}

Trace

\begin{tabular}{|c|c|c|c|}
\hline \multicolumn{4}{|c|}{ Substitution content (\%) } \\
\hline \multicolumn{2}{|c|}{ Trace } & Tire & CBC \\
\hline TO & $0 \%$ & $0 \%$ & $0 \%$ \\
\hline $\mathrm{T1}$ & $25 \%$ & $0 \%$ & $25 \%$ \\
\hline $\mathrm{T} 2$ & $5 \%$ & $0 \%$ & $5 \%$ \\
\hline T3 & $5 \%$ & $5 \%$ & $0 \%$ \\
\hline T4 & $2 \%$ & $2 \%$ & $0 \%$ \\
\hline T5 & $27 \%$ & $2 \%$ & $25 \%$ \\
\hline T6 & $7 \%$ & $2 \%$ & $5 \%$ \\
\hline $\mathrm{T7}$ & $30 \%$ & $5 \%$ & $25 \%$ \\
\hline T8 & $10 \%$ & $5 \%$ & $5 \%$ \\
\hline
\end{tabular}



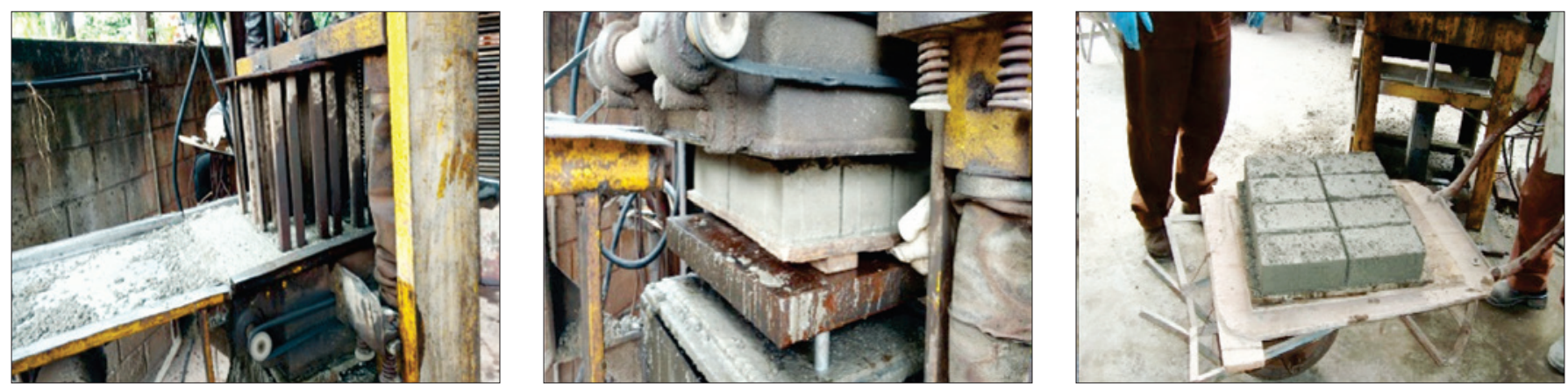

\section{Figure 4}

Pavers production

corrections during the molding process.

The measurement of the materials to make all the traces was made in mass, in order to guarantee a greater rigor in the control of the production. Figure 4 shows the production sequence of the parts. The pavers were left in the factory yard for 48 hours, being wet three times a day, after this period they were taken to the Construction Materials Laboratory of the State University of Maringá where they remained in the Wet Chamber until the tests provided for in the Experimental Program were performed.

\subsubsection{Visual Inspection: dimensions, weight and color}

Six pieces of each trait were separated at the age of 28 days for visual inspection, which consists of measuring, weighing and color checking. The parameters of weight and color are not defined in standard, but were adopted to verify any change between molded parts with addition of residues and reference parts. As for the dimensional parameter, NBR 9781: 2013 (ABNT: 2013) ${ }^{[18]} \mathrm{de}-$ termines that the pieces are measured in their three dimensions, thickness, width and height, and there can be no variation of $3 \mathrm{~mm}$

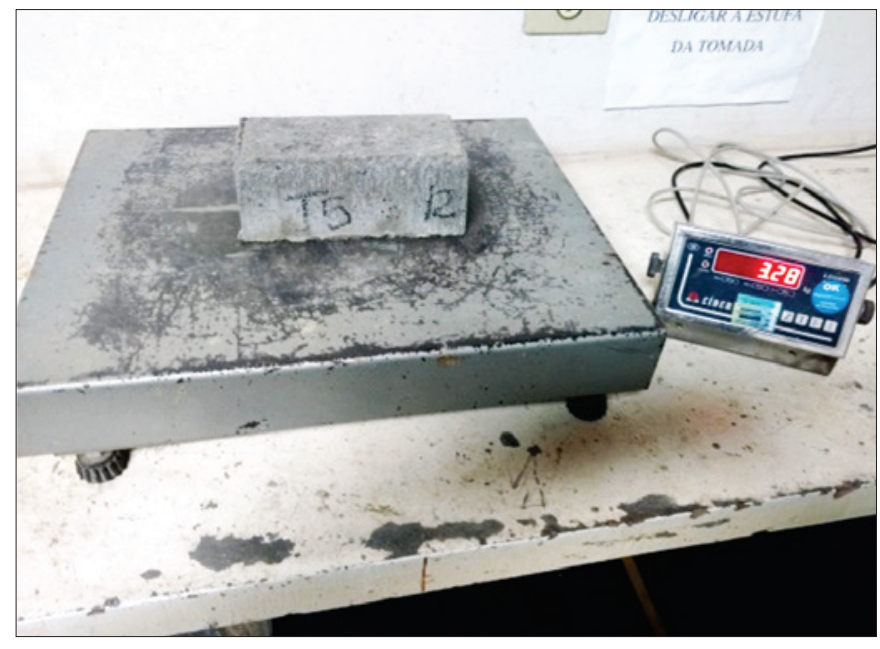

(A) in any of the three. The pieces, at 28 days, were separated, measured, weighed and analyzed for color as shown in Figure 5

\subsubsection{Compressive strength test}

The compressive strength test is taken as a parameter by most national and international standards, so this characteristic is of utmost importance in evaluating the performance of pavers.

In this work the study of this property is one of the characteristics that defines the viability of substitution of the small aggregate by the residues. This substitution directly interferes in the compressive strength of the concrete, either by its decrease in the case of the tire residue or by its increase in the case of the BCC. In addition, the combined substitution will also be studied.

For the compressive strength test, 18 pavers were manufactured for each of the first defined traces, which were tested at age 28 days, as defined by NBR 9781: 2013 (ABNT, 2013) ${ }^{[18]}$

The test performed followed ABNT NBR 9781: 2103 (Concrete Paving Parts - Specification and Test Methods) ${ }^{[18]}$, which admits that all other characteristics of the pavers are directly attached to this

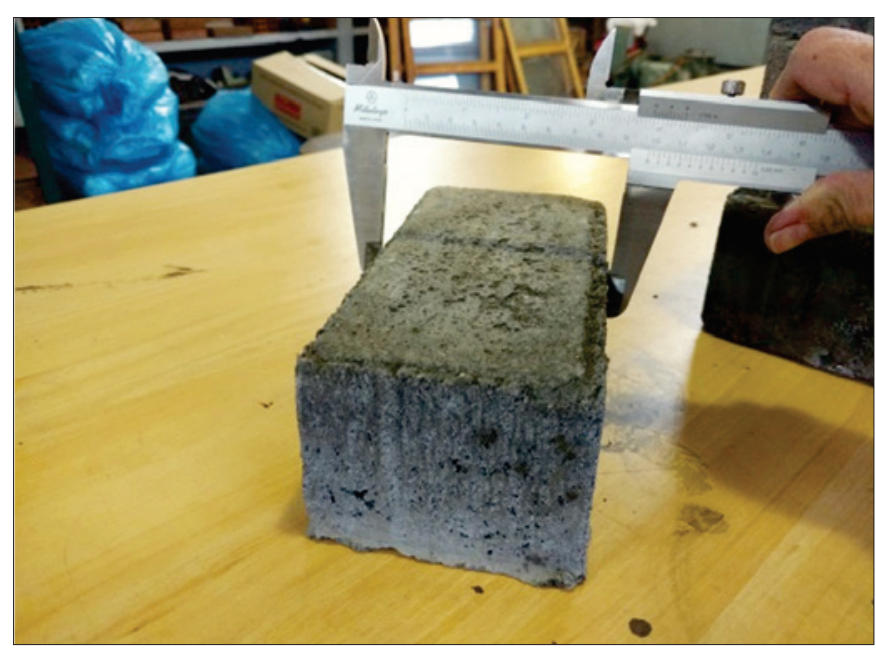

(B)

Figure 5

Parts inspection and measurement: (A) Weighing of parts; (B) Dimension measurement of parts 


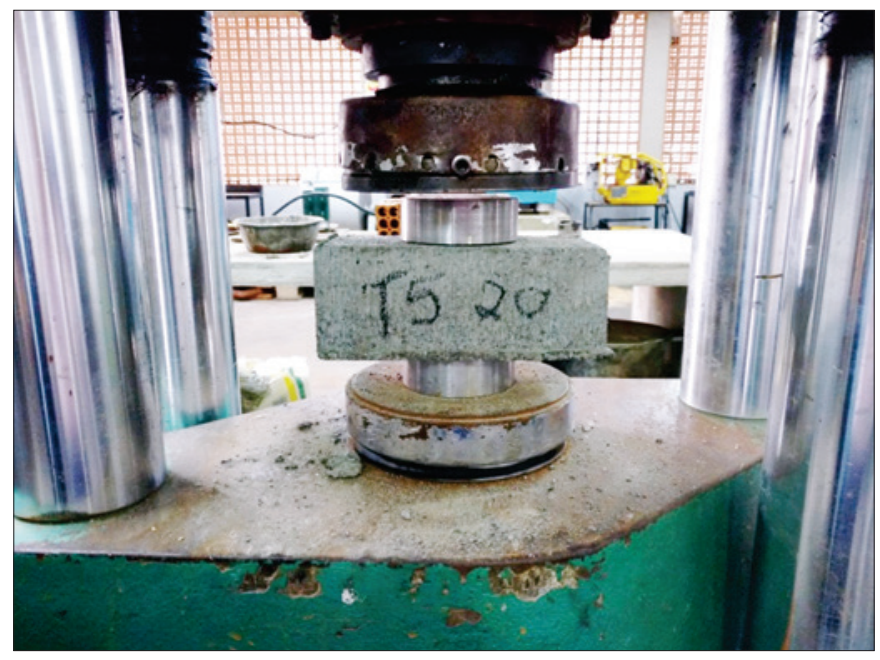

Figure 6

Paver in the press between the discs

property. For the tests, the pavers were rectified and immersed in water for 24 hours, as required by the standard, and tested in the equipment provided by the laboratory, a Universal Testing Machine (MEU) of the EMIC brand. Figure 6 shows a paver being compressed.

\subsubsection{Water absorption test}

According to NBR 9781: 2013 (ABNT, 2013) ${ }^{[18]}$ water absorption, expressed as a percentage, represents the increase in mass of a porous solid body due to the penetration of water into its permeable pores, relative to its state mass dry. According to Fioriti (2007) [22], immersion water absorption is related to the measurement of the pore volume of

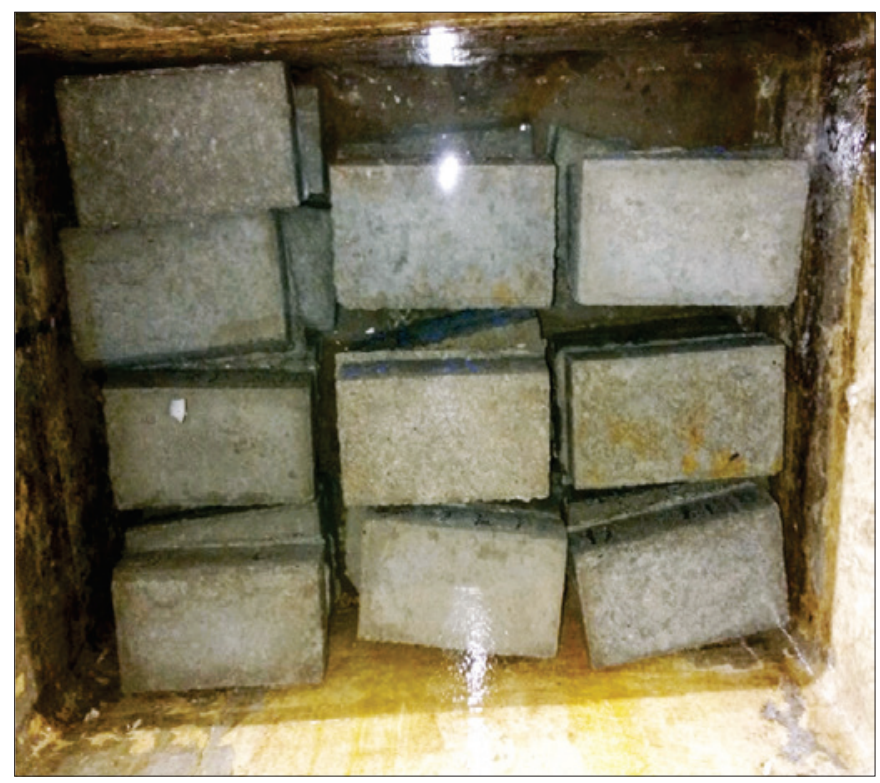

(A) the concrete, not to the ease with which the fluid penetrates the concrete. The water absorption is closely linked to the voids (pores) in the cement matrix. The greater the porosity of the pieces, the greater their water absorption. These unfilled spaces may cause loss of durability and mechanical strength of the parts, as well as increased leaching of the chemical substances contained in it. The experiment was based on NBR 9781: 2013 (ABNT, 2013) ${ }^{[18]}$. For the test three pavers were used for each trait at the age of 28 days, Figure 7 shows the pavers immersed in water and also dried in the greenhouse.

\subsubsection{Abrasion resistance test}

The abrasion is directly linked to the pavement's resistance to wear, being as important as the other properties required of the pavers. NBR 9781: 2013 (ABNT: 2013) ${ }^{[18]}$ provides and describes the abrasion test, but makes it an optional choice. Because it is not a mandatory test and because it is not very common, both manufacturing companies and researchers still adopt other methods to study this parameter. Among the several possibilities, the method used to determine pavers abrasion was the CIENTEC Method, available in Rio Grande do Sul. One paver was tested for the trait as an optimum substitution for the parameter of resistance to compression, with age of 28 days, since this is an expensive trial. The proposal is to make a comparison between the trait with optimal content and the reference trait.

\section{Results and discussions}

\subsection{Characterization of materials}

\subsubsection{Aglomerant}

The cement used was Portland Cement of Initial High Strength

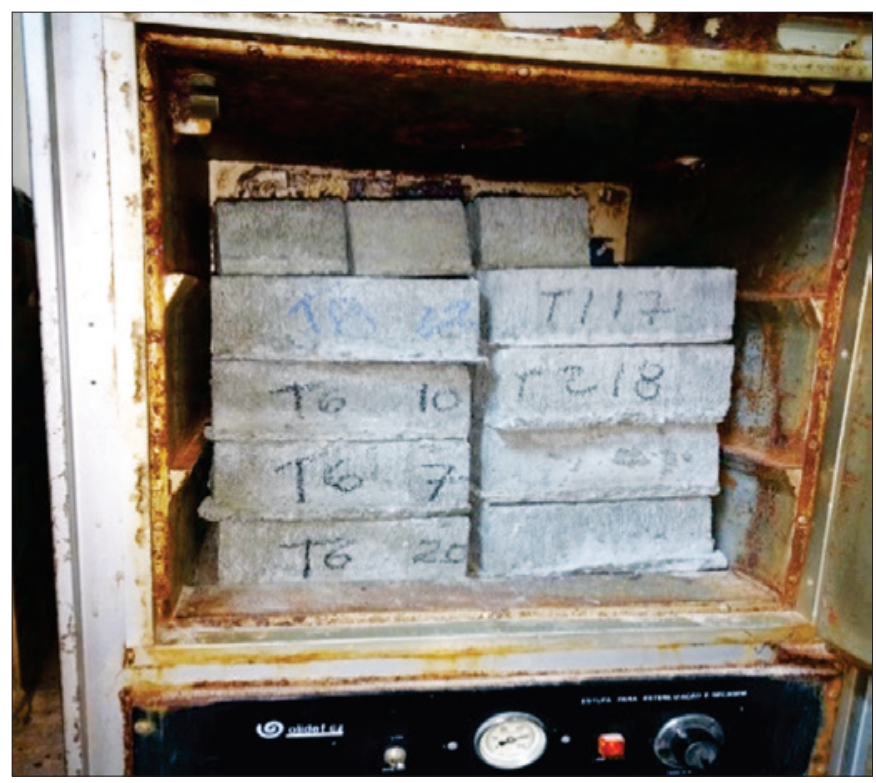

(B)

Figure 7

Absorption tests: (A) Immersed pavers; (B) Pavers in the greenhouse 
Waste tires and the burning of sugarcane bagasse in the manufacture of concrete pavers (pavers)

Table 3

Cement features CP V ARI

\begin{tabular}{cccc}
\hline $\begin{array}{c}\text { Item de } \\
\text { controle }\end{array}$ & Unit & $\begin{array}{c}\text { Manufacturer } \\
\text { data }\end{array}$ & $\begin{array}{c}\text { NBR 5737/ } \\
\text { NBR 5733 }\end{array}$ \\
\hline $\begin{array}{c}\text { Strength } \\
24 \text { horas }\end{array}$ & $\mathrm{MPa}$ & 27 & $>14$ \\
$\begin{array}{c}\text { Strength } \\
3 \text { dias }\end{array}$ & $\mathrm{MPa}$ & 37 & $>24$ \\
$\begin{array}{c}\text { Strength dias } \\
\text { Strength }\end{array}$ & $\mathrm{MPa}$ & 42 & $>34$ \\
28 dias & $\mathrm{MPa}$ & 48 & - \\
$\begin{array}{c}\text { Blaine } \\
\text { Start of } \\
\text { handle } \\
\text { End of } \\
\text { handle }\end{array}$ & $\mathrm{cm}^{2} / \mathrm{g}$ & 5330 & $>3000$ \\
\hline
\end{tabular}

Source: Cauê, 2016

Table 4

Characterization of the small aggregate

\begin{tabular}{ccc}
\hline Characterization & Units & Values \\
\hline Especific mass & $\mathrm{g} / \mathrm{cm}^{3}$ & 2,655 \\
Single unit mass in the loose state & $\mathrm{g} / \mathrm{cm}^{3}$ & 1,635 \\
Characteristic maximum diameter & $\mathrm{mm}$ & 1.2 \\
Modulus of fineness & - & 1.68 \\
\hline
\end{tabular}

( $C P \vee A R I)$, which gives the pieces high initial resistance already at the beginning of the curing process. The characteristics of the material were obtained from the manufacturer and are listed in Table 3 and meet the Brazilian standards regarding the minimum quality limit.

\subsubsection{Small aggregate}

The results of the small aggregate characterization tests: determination of specific mass, unit mass in the loose state, characteristic maximum diameter and fineness modulus are shown in Table 4 and Figure 8 shows the granulometric distribution curve.
Table 5

Characterization of the aggregate

\begin{tabular}{ccc}
\hline Characterization & Units & Values \\
\hline Especific mass & $\mathrm{g} / \mathrm{cm}^{3}$ & 2,900 \\
Single unit mass in the loose state & $\mathrm{g} / \mathrm{cm}^{3}$ & 1,516 \\
Characteristic maximum diameter & $\mathrm{mm}$ & 6.30 \\
Modulus of fineness & - & 4.49 \\
\hline
\end{tabular}

\subsubsection{Large aggregate}

The results of the large aggregate characterization tests: determination of specific mass, unit mass in the loose state, characteristic maximum diameter and fineness modulus are given in Table 5 and Figure 9 shows the granulometric distribution curve.

\subsubsection{Sugarcane bagasse ash - СВC}

\subsubsection{POZOLANIC ACTIVITY}

The pozzolanic activity assay was performed at the IPT-São Paulo Technological Research Institute following the Modified Chapelle Method according to the guidelines of NBR 15895: 2010 (ABNT, 2010) ${ }^{[12]}$ and the IPT123-CT-OBRAS-LMCC- Q-PE-041 - Revision 1 [25]. The sample analyzed presented a pozzolanic activity index of $137 \mathrm{mg} \mathrm{Ca}(\mathrm{OH}) 2$ / g of the sample, which according to NBR 15894-1: 2010 (ABNT, 2010) ${ }^{[12]}$ is not indicative of pozzolanic material once that in order to be characterized in this way the material needs to have an index greater than or equal to $750 \mathrm{mg} \mathrm{Ca}(\mathrm{OH}) 2$ / g.

\subsubsection{GRANULOMETRIC ANALYSIS}

The granulometric analysis was performed by the combination of sieving and sedimentation following NBR 7181: 1984 (ABNT, $1984)^{[13]}$, Figure 10 shows the result of the test performed.

As can be observed in the granulometric distribution curve $79 \%$ of the ash was retained between the sieves 0.06 to $0.2 \mathrm{~mm}$, in the classification of NBR 6508: 1995 (ABNT, 1995) ${ }^{[14]}$ they are similar to fine sands. The sample had a uniformity value of 1.25 which

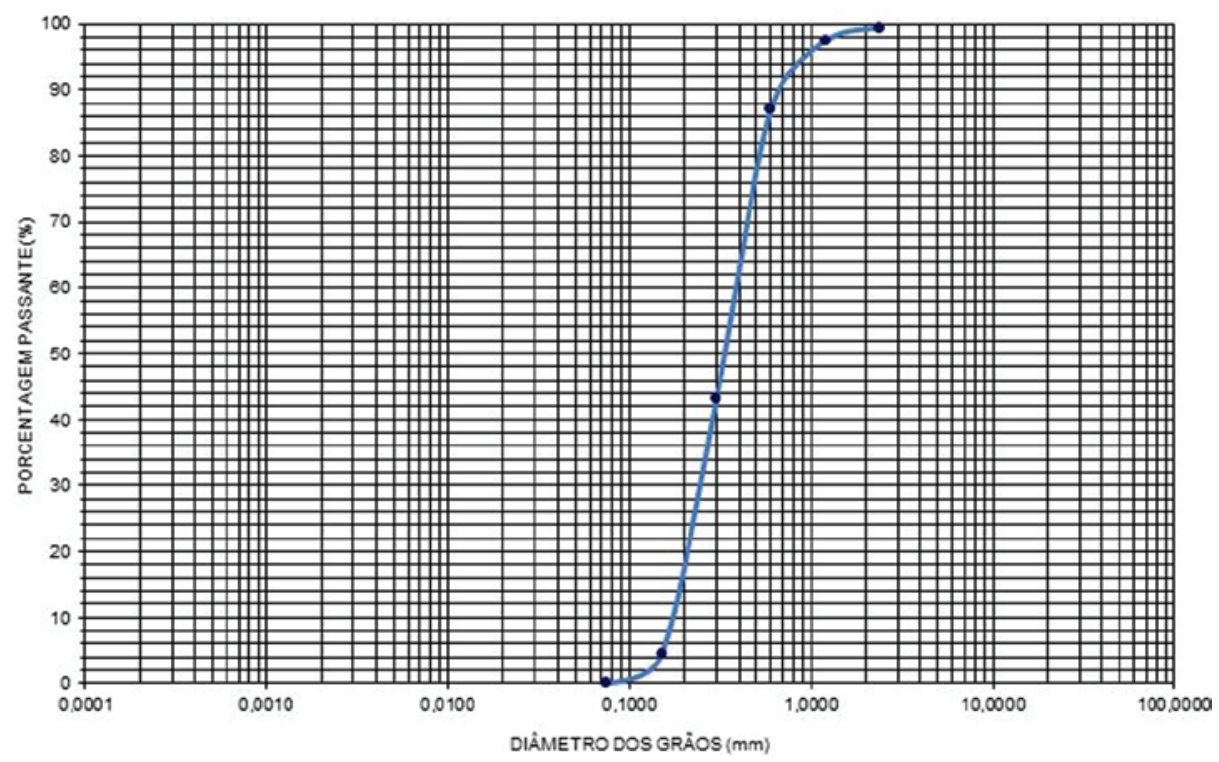

Figure 8

Curve aggregate granulometric distribution 


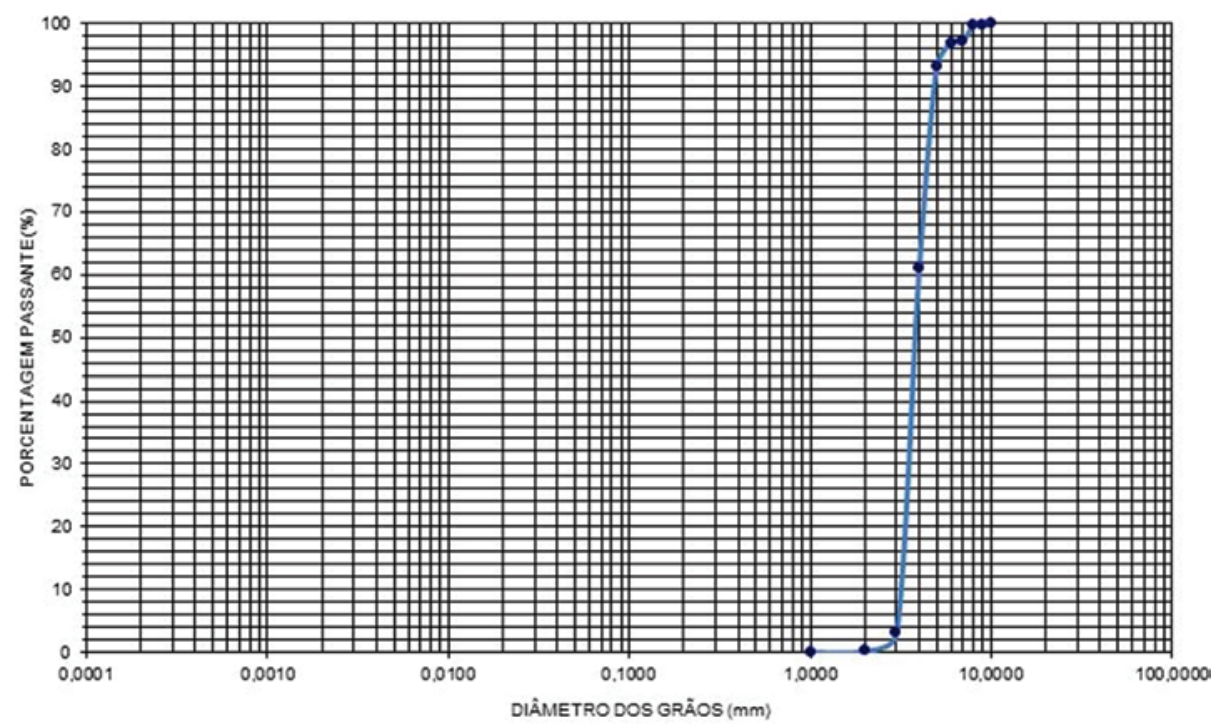

\section{Figure 9}

Curve aggregate granulometric distribution

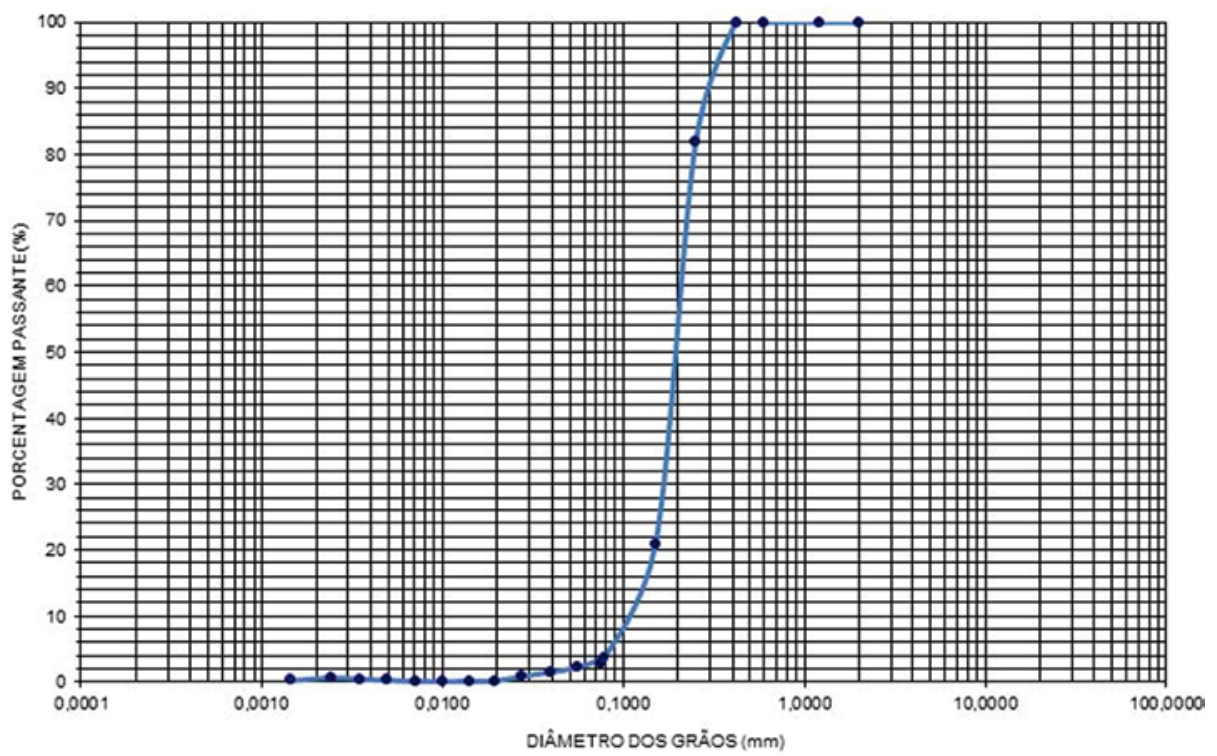

Figure 10

Granulometric curve - CBC

indicates an almost vertical granulometric curve, ie the diameters vary in a small range, indicating a sample with uniform distribution. The graduation of the sample can be classified with a good grade with a value of the particle size distribution coefficient close to 1 .

\subsubsection{SPECIFIC MASS AND MOISTURE CONTENT}

The results of the assay for specific mass determination, performed according to the methodology proposed in ABNT NBR 6508: 1984 (ABNT, 1984)) ${ }^{[14]}$, are shown in Table 6. The moisture content of the sample is shown in Table 6.

The value of the specific mass of the ash was very close to the value of the sand used in this work, whose specific mass value was $2.65 \mathrm{~g} / \mathrm{cm}^{3}$.

\subsubsection{LEACHING AND SOLUBILIZATION TESTS}

The values of the leached extract test were kept within the parameters established by Annex F of NBR 10004: 2004 (ABNT, 2004) [17], thus classifying CBC as a "NON-HAZARDOUS" residue. Some of the results for solubilization were found to be above that allowed by NBR 10004: 2004 (ABNT, 2004) [17], in its Annex F, therefore, this residue falls within the non-inert class. Thus, according to NBR 10004: 2004 (ABNT, 2004) [17], the analyzed CBC sample can be classified by 


\section{Table 6}

Specific mass and moisture content of CBC

\begin{tabular}{|c|c|c|c|}
\hline \multicolumn{4}{|c|}{ Especific mass } \\
\hline \multirow{2}{*}{ Item } & & \multicolumn{2}{|c|}{ Sample } \\
\hline & & 1 & 2 \\
\hline Capacity of the picnometer (ml) & - & $22 / 500$ & $24 / 200$ \\
\hline Wet sample $(\mathrm{g})$ & $\mathrm{P} 1$ & 60 & 60 \\
\hline Dry sample (g) & - & 59,92 & 59,92 \\
\hline Picnometer+ ground + water (g) & $\mathrm{P} 2$ & 654,34 & 648,04 \\
\hline Picnometer + water & P3 & 616,56 & 610,22 \\
\hline Temperature test $\left({ }^{\circ} \mathrm{C}\right)$ & - & 24,8 & 25,0 \\
\hline Specific mass of water $\left(\mathrm{g} / \mathrm{cm}^{3}\right)$ & - & 0,9971 & 0,9971 \\
\hline Especific mass of ground $\left(\mathrm{g} / \mathrm{cm}^{3}\right)$ & Gs & 2,70 & 2,70 \\
\hline Especific mass of grouns $\left(\mathrm{g} / \mathrm{cm}^{3}\right)$ & Gs & 2,70 & 2,70 \\
\hline \multicolumn{4}{|c|}{ Determination of moisture content } \\
\hline Capsule $\mathrm{n}^{\circ}$ & 20 & 50 & 78 \\
\hline Wet sample + Capsule (g) & 76,69 & 83,64 & 72,87 \\
\hline Dry sample + Capsule (g) & 76,61 & 83,54 & 72,81 \\
\hline Capsule mass (g) & 18,35 & 18,27 & 14,35 \\
\hline Moisture (\%) & 0,14 & 0,15 & 0,10 \\
\hline Average & & 0,13 & \\
\hline
\end{tabular}

the parameters presented here as "Non-hazardous waste - Class II A - Non-inert". Residues with such a classification may have biodegradability, combustibility or water solubility properties.

This condition of the $\mathrm{CBC}$, being a non-inert material, can cause it to be released directly into the soil may cause some type of contamination in the long term, remembering that the direct launching in plantations is the method usually employed for CBC. This information justifies once again the use of $\mathrm{BCC}$ as an aggregate in the manufacture of concretes and pavers, since the concrete can lead to the encapsulation of the contaminating materials, mitigating the possible contaminations. The tests of solubilization and leaching in the pavers were also carried out, aiming to confirm the neutraliza- tion and stabilization efficiency of the contaminants present in the residues used in the manufacture of the parts.

\subsubsection{Residual tire}

\subsubsection{GRANULOMETRIC ANALYSIS}

The granulometric analysis was performed according to the normalized by NBR NM 248: 2003 (ABNT, 2003) [8]. Figure 11 and Table 7 present, respectively, the grain size curve and the grain size characteristics of the waste tire residue. The tire residue presents granulometric characteristics of materials with uniform

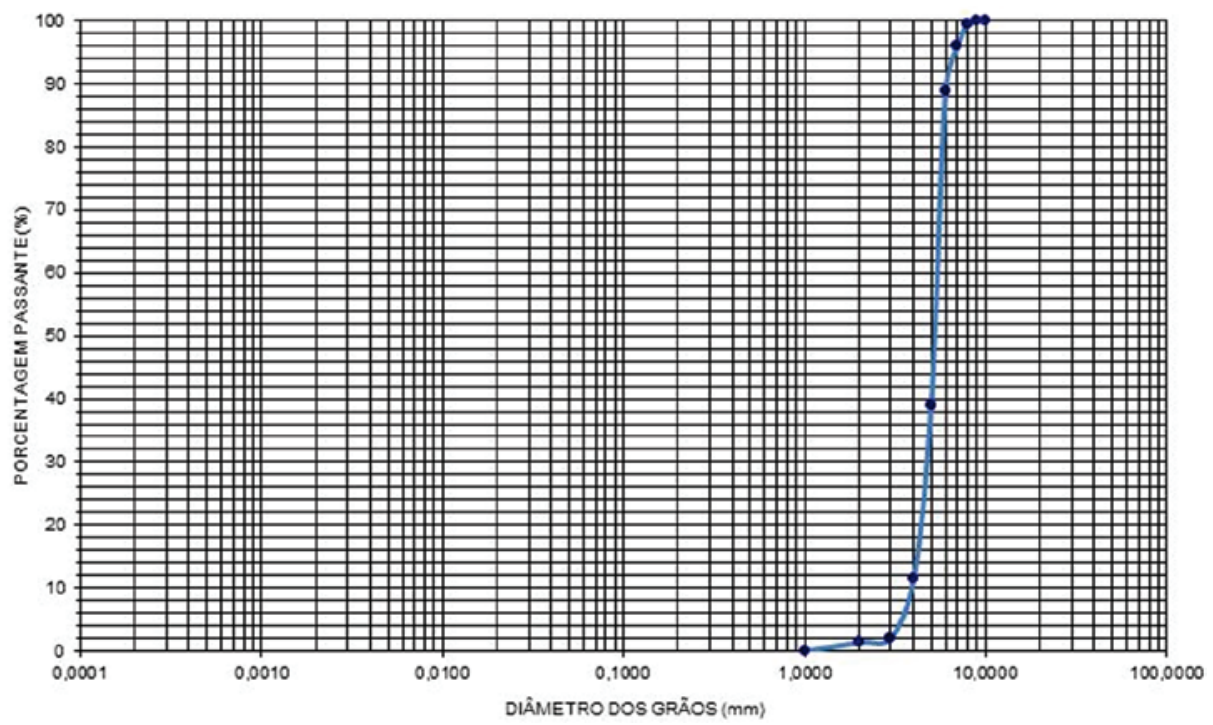

Figure 11

Granulometric curve - tire residue 
Table 7

Granulometric characteristics - tire residue

\begin{tabular}{cc}
\hline Property & Tire residue \\
\hline Maximum diameter & $2,4 \mathrm{~mm}$ \\
Modulus of fineness & 4,14 \\
Ranking (NBR 7211/2009) & Coarse sand \\
\hline
\end{tabular}

granulometry, as can be observed by its grain size curve. The granulometric composition has a direct influence on the workability of the concrete (NEVILLE, 1995) ${ }^{[21]}$ and its densification, which leads to a higher resistance, since the more dense the concrete the greater its resistance (FIORITI, 2007) $)^{[22]}$.

\subsubsection{UNITARY MASS}

In order to determine the unit mass of the tire residue, the test used for aggregates with a characteristic size of less than $37.5 \mathrm{~mm}$ was performed, following the procedure described in NBR NM 45: 2006 (ABNT, 2006) ${ }^{[9]}$, the result being the same to $1.67 \mathrm{~g} / \mathrm{cm} 3$.

\subsubsection{ESPECIFIC MASS}

Table 8 gives the results of the test for determination of specific mass, performed according to the methodology proposed in NBR 6508: 1984 (ABNT, 1984) ${ }^{[14]}$. The tire residue has a specific grain mass less than the specific mass of the small aggregate used in the construction of the pavers, which may contribute to a lighter product.

\subsubsection{LEACHING AND SOLUBILIZATION TESTS}

The values of the leached extract test were kept within the parameters established in Annex F of ABNT NBR 10004: 2004) [17], thus classifying the tire residue as "NON-HAZARDOUS" waste. Some of the results for solubilization are above that allowed by NBR 10004: 2004) ${ }^{[17]}$ in its Annex F, therefore, this residue falls into the non-inert class. Accordingly, in accordance with NBR 10004 [17], all samples of the Residual Tire Residue analyzed can be classified by the parameters presented here as "Non-hazardous waste - Class II A - Non inert". Residues with such a classification may have biodegradability, combustibility or water solubility properties. Like CBC, the tire residue is also a non-inert material, which can lead to some contamination of both soil and water if it is disposed of inappropriately in the environment. In order to verify if the contaminants were encapsulated by the concrete the tests of solubilization and leaching in the pavers were also carried out, trying to confirm the efficiency of the application.

\subsubsection{DOSING OF PAVERS}

The dosage adopted was established by Amadei (2011) $)^{[19]}$ and also used by Altoé $(2013){ }^{[6]}$. The trace has a ratio of aggregate to binder 1: 4 . With the granulometric curves of the aggregates the dosage was adjusted according to the methodology proposed by Fernandes (2012) ${ }^{[20]}$. Figure 12 shows the granulometric curve of the mixture defined according to the proposed methodology.

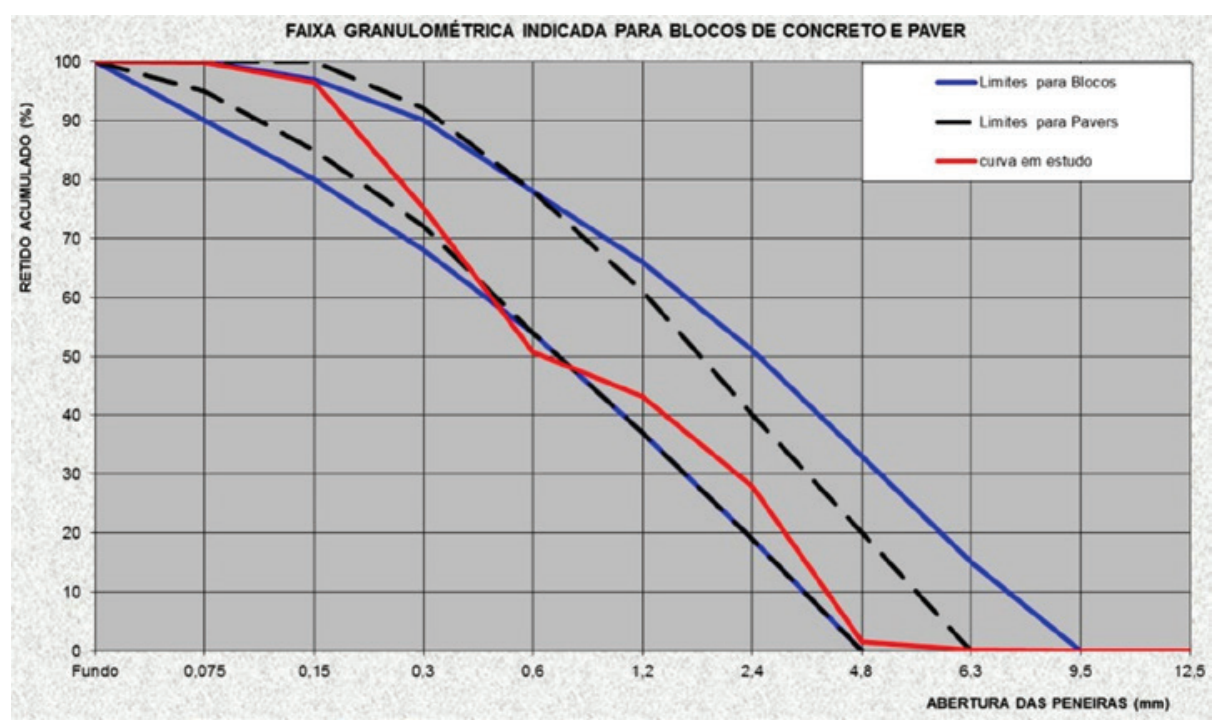

Figure 12

Granulometric curve of the mixture

Table 8

Especific mass - tire residue

\begin{tabular}{|c|c|c|c|}
\hline \multirow{2}{*}{ Item } & & \multicolumn{2}{|c|}{ Sample } \\
\hline & & 1 & 2 \\
\hline Capacity of the picnometer (ml) & - & $22 / 500$ & $24 / 500$ \\
\hline Wet Sample $(\mathrm{g})$ & $\mathrm{P} 1$ & 16,43 & 17,31 \\
\hline Dry Sample (g) & - & 16,43 & 17,31 \\
\hline Picnometer + ground + water $(\mathrm{g})$ & P2 & 589,03 & 582,00 \\
\hline Picnometer + water & P3 & 610,98 & 604,57 \\
\hline Temperature test $\left({ }^{\circ} \mathrm{C}\right)$ & Gs & 0,43 & 0,43 \\
\hline Specific mass of water $\left(\mathrm{g} / \mathrm{cm}^{3}\right)$ & Gs (médio) & & \\
\hline
\end{tabular}


Table 9

Mass dosing of pavers

\begin{tabular}{cccccccc}
\hline Trace & $\begin{array}{c}\text { Cement } \\
(\mathrm{kg})\end{array}$ & $\begin{array}{c}\text { Sand } \\
(\mathrm{kg})\end{array}$ & $\begin{array}{c}\text { Tire } \\
(\mathrm{kg})\end{array}$ & $\begin{array}{c}\text { CBC } \\
(\mathrm{kg})\end{array}$ & $\begin{array}{c}\text { Ahil } \\
(\mathrm{kg})\end{array}$ & $\begin{array}{c}\text { Additive } \\
\text { ml }\end{array}$ \\
\hline T0 & 18 & 47,7 & 0 & 0 & 24,3 & 0,42 & 40 \\
T1 & 18 & 35,78 & 0 & 11,93 & 24,3 & 0,42 & 40 \\
T2 & 18 & 45,32 & 0 & 2,39 & 24,3 & 0,42 & 40 \\
T3 & 18 & 45,32 & 2,39 & 0 & 24,3 & 0,42 & 40 \\
T4 & 18 & 46,98 & 0,72 & 0 & 24,3 & 0,42 & 40 \\
T5 & 18 & 35,06 & 0,72 & 11,93 & 24,3 & 0,42 & 40 \\
T6 & 18 & 44,60 & 0,72 & 2,39 & 24,3 & 0,42 & 40 \\
T7 & 18 & 33,39 & 2,39 & 11,93 & 24,3 & 0,42 & 40 \\
T8 & 18 & 42,93 & 2,39 & 2,39 & 24,3 & 0,42 & 40 \\
\hline
\end{tabular}

The proportion determined by Amadei (2011 ${ }^{[19]}$ was adequate for the manufacture of pavers, according to the granulometric curve of the mixture, being within the limits of the optimal curve determined by Fernandes (2012) ${ }^{[20]}$. Thus, the proportion defined was $55 \%$ of small aggregate and $45 \%$ of large aggregate. After the dosing was defined, the replacement levels were established, based on the results of the Altoé $(2013)^{[6]}$ research, based on the principle of maximum use of the proposed residues. Table 9 shows the mass dosages used to manufacture the pavers. After the traces were defined, the pieces were molded in the Concrete Artifacts Factory of the State University of Maringá

\subsection{Properties of pavers}

\subsubsection{Visual inspection}

\subsubsection{COLOR AND VISUAL ASPECT}

The visual aspect of the pavers is of extreme importance, since the developed material must present visual characteristics close to the commercial pavers. According to the manufacturer Maski (2010) ${ }^{[23]}$, the paver should have well defined edges, good sur-

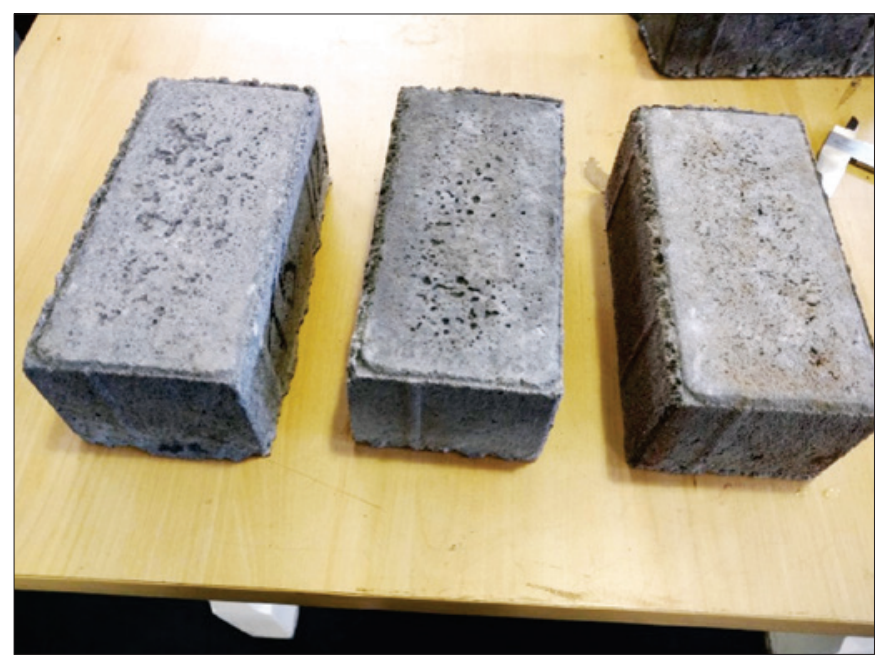

Figure 13

Pavers made from waste face finish and no burrs. In addition, color is also an important aesthetic factor when defining which material will be applied on a sidewalk.

For this reason an inspection was carried out in order to verify the conformity of the parts and if there was any variation of color in the parts manufactured with waste. Figure 13 shows some of the pavers made with the proposed waste. There was not a considerable variation in the color of the pieces, since the applied residue, despite having a darker coloration than the natural aggregate, the amount replaced was not enough to influence this question.

\subsubsection{Mass of pavers}

The parts were weighed and the average values found for each trace are given in Table 10.

The results show that the substitution of $B C C$ results in a small increase in the mass of the pieces. This can be explained by the difference in mass between the two residues and the natural aggregate. On the other hand, the pieces manufactured with waste tires had their mass reduced as expected, even in the parts manufactured with traces that also contained CBC

\section{Table 10}

Average weight of pavers

\begin{tabular}{cccc}
\hline & Trace & $\begin{array}{c}\text { Average } \\
\text { weight of } \\
\text { pavers } \\
\text { (g) }\end{array}$ & $\begin{array}{c}\text { Variation in } \\
\text { relation to T0 } \\
\%\end{array}$ \\
\hline T0 & - & $3.277,22$ & - \\
T1 & $25 \%$ CBC & $3.304,44$ & 0,83 \\
T2 & $5 \%$ CBC & $3.312,78$ & 1,08 \\
T3 & $5 \%$ Tire & $3.086,67$ & $-5,81$ \\
T4 & $2 \%$ Tire & $3.240,00$ & $-1,14$ \\
T5 & $25 \%$ CBC & $3.250,00$ & $-0,83$ \\
& $2 \%$ tire & & \\
T6 & $5 \%$ CBC & $3.275,56$ & $-0,05$ \\
& $2 \%$ tire & & $-1,27$ \\
T7 & $25 \%$ CBC & $3.235,56$ & $-1,07$ \\
& $5 \%$ tire & & \\
T8 & $5 \%$ CBC & $3.242,22$ & -140 \\
\hline
\end{tabular}


Table 11

Dimensional variation of pavers in relation to dimensional tolerance

\begin{tabular}{|c|c|c|c|c|c|c|}
\hline \multirow[b]{2}{*}{ Trace } & \multicolumn{2}{|c|}{ Length } & \multicolumn{2}{|c|}{ Width } & \multicolumn{2}{|c|}{ Thickness } \\
\hline & $\begin{array}{c}\text { Measure } \\
(\mathrm{mm})\end{array}$ & $\begin{array}{l}\text { Variation } \\
(\mathrm{mm})\end{array}$ & $\begin{array}{l}\text { Measure } \\
(\mathrm{mm})\end{array}$ & $\begin{array}{l}\text { Variation } \\
(\mathrm{mm})\end{array}$ & $\begin{array}{l}\text { Measure } \\
(\mathrm{mm})\end{array}$ & $\begin{array}{c}\text { Variation } \\
(\mathrm{mm})\end{array}$ \\
\hline Forma & 195 & - & 95 & - & 80 & - \\
\hline TO & 196 & 1 & 95 & 0 & 79 & -1 \\
\hline $\mathrm{T1}$ & 196 & 1 & 95 & 0 & 81 & 1 \\
\hline $\mathrm{T} 2$ & 195 & 0 & 95 & 0 & 80 & 0 \\
\hline T3 & 196 & 1 & 95 & 0 & 80 & 0 \\
\hline $\mathrm{T} 4$ & 196 & 0 & 96 & 1 & 80 & 0 \\
\hline T6 & 195 & 0 & 95 & 0 & 80 & 0 \\
\hline $\mathrm{T7}$ & 195 & 0 & 95 & 0 & 80 & 0 \\
\hline T8 & 195 & 0 & 95 & 0 & 80 & 0 \\
\hline
\end{tabular}

\subsubsection{DIMENSIONS}

The NBR 9781: 2013 (ABNT, 2013) ${ }^{[18]}$ defines that the dimensional tolerance of pavers should be $3 \mathrm{~mm}$ for width, length and thickness. This requirement is given, because the dimensional variation directly interferes with the alignment and the seating of the pieces. For the analysis of this parameter, measurements were made on 18 pavers made by dash, to be calculated the average of the dimensions. The results are shown in Table 11, and the dimensions of the pavers manufactured should be $(195 \times 95 \times 8)$ $\mathrm{mm}$., Both traces presented average dimensions within the dimensional tolerances.

\subsubsection{COMPRESSIVE STRENGTH}

According to NBR 9781: 2013 (ABNT, 2013) ${ }^{[18]}$ and following the methodology described in Annex $A$, pavers manufactured with different substitution contents were tested under compression in order to determine the estimated compressive strength of each stroke. The results of the tests are shown in Table 12. In order

\section{Table 12}

Compressive strength average and estimated characteristic

\begin{tabular}{cccc}
\hline \multirow{2}{*}{ Trace } & \multicolumn{2}{c}{$\mathbf{2 8 \text { dias }}$} \\
\cline { 3 - 4 } & & $\mathbf{f}_{\mathrm{p}}$ (MPa) & $\mathbf{f}_{\mathrm{pk}, \text { est }}$ (MPa) \\
\hline $\mathrm{T} 0$ & - & 35,32 & 33,83 \\
$\mathrm{~T} 1$ & $25 \% \mathrm{CBC}$ & 40,72 & 39,19 \\
$\mathrm{~T} 2$ & $5 \% \mathrm{CBC}$ & 35,08 & 33,11 \\
$\mathrm{~T} 3$ & $5 \%$ tire & 25,35 & 23,07 \\
$\mathrm{~T} 4$ & $2 \%$ tire & 30,77 & 29,00 \\
$\mathrm{~T} 5$ & $25 \%$ CBC & 35,16 & 32,22 \\
& $2 \%$ tire & & \\
$\mathrm{T} 6$ & $5 \%$ CBC & 31,72 & 29,55 \\
& $2 \%$ tire & & \\
$\mathrm{T} 7$ & $25 \%$ CBC & 28,30 & 26,17 \\
& $5 \%$ tire & & \\
T8 & $5 \%$ CBC & 21,79 & 20,35 \\
\hline
\end{tabular}

to facilitate the analysis of data, the results were transferred to a graph, shown in Figure 14.

The trait that obtained the best result according to the resistance parameters required by NBR 9781: 2013 (ABNT, 2013) ${ }^{[18]}$ was T1, manufactured with $25 \%$ sand replacement per $B C C$, with a value of $39.19 \mathrm{MPa}$, reaching an increase of $15.89 \%$ in relation to the reference trait. The $\mathrm{T} 2$ trace also made with $\mathrm{CBC}$ in substitution for the sand presented similar result to the reference trait. These results demonstrate the feasibility of the use of this residue in the preparation of pavers, without compromising the compressive strength. As already pointed out in several studies, there is a decrease in compressive strength when sand is replaced by tire residue. For this research, traces with $2 \%$ and $5 \%$ of substitution were studied, and both presented a reduction in relation to the T0 trace, with values of 23.07 MPa and $29 \mathrm{MPa}$, for T3 and T4 respectively. The substitution of $2 \%$ (T4) for the loss of resistance was not as significant as that of $5 \%$ (T3), being in the order of $14 \%$, the compressive strengths obtained are lower than that determined by NBR 9781: 1987 (ABNT, $1987)^{[19]}$. However, they reached values that, according to several researchers, may be indicated for application in places subject to light applications, since, secondly, a resistance of $15 \mathrm{MPa}$ would already be the ideal for this type of request (FIORITI , 2007) ${ }^{[22] .}$

The traces made with the two residues together show that the mixture of $\mathrm{CBC}$ with tire offers an improvement in the mechanical

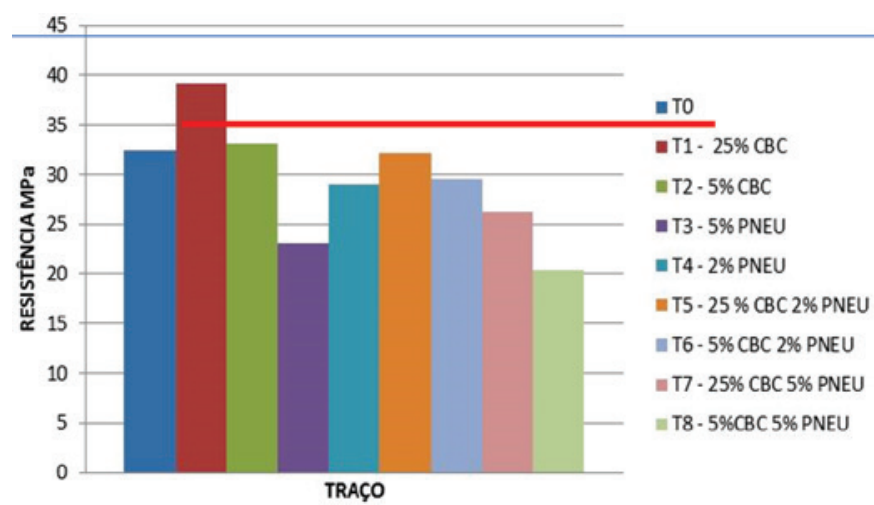

Figure 14

Compressive strength 


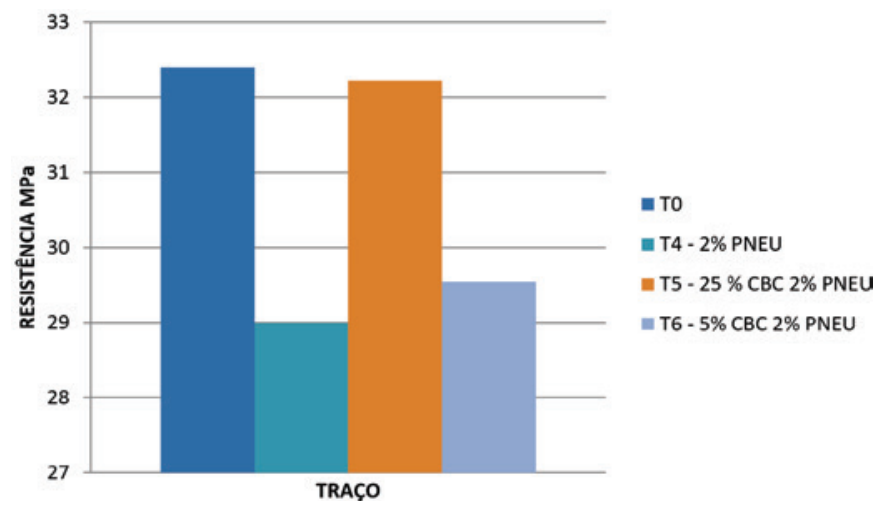

Figure 15

Compressive strength Tire $2 \%$

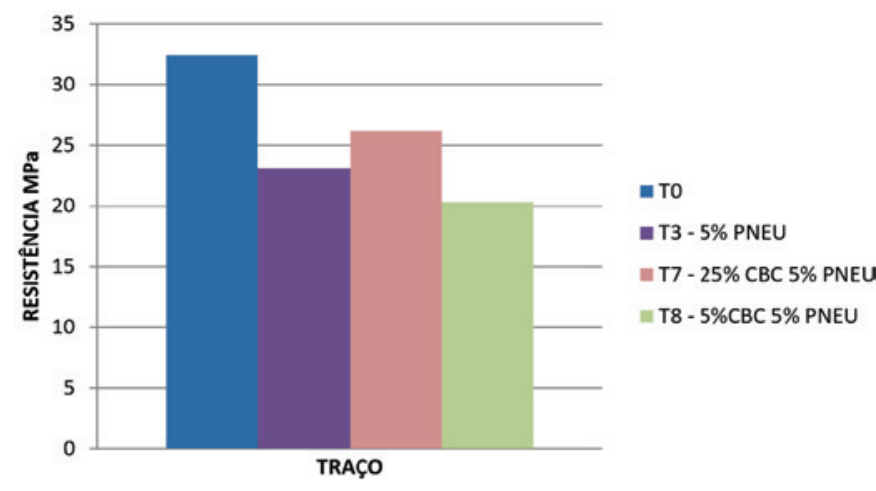

Figure 16

Compressive strength Tire 5\%

properties of the paver made with only tire residue. In order to better visualize these results, the graphs presented in Figures 15 and 16 , where the results of $2 \%$ and $5 \%$ of sand replacement by Tire are presented together with $5 \%$ and $25 \%$ CBC contents.

According to Figure 15 the pavers where the sand was replaced by CBC and Tire achieved better compressive strength results than where only the tire was used, with an increase of $11.10 \%$ in T5. Another factor to be observed was that this trait presented a reduction of less than $5 \%$ in relation to T0. In this trait the total substitution content is $27 \%$ of the sand per residue, a high index when compared to other residues when applied with the same purpose. In the case of pavers made with $5 \%$ of tire residue, this behavior is repeated for the CBC content of $25 \%$. At $5 \%$ CBC, the results did not show improvement, as can be seen in Figure 16.

One behavior that can be observed with respect to compressive strength is that this apparently does not influence when the substitution content is $5 \%$ substitution, as can be seen in the T2, T6 and $\mathrm{T} 8$ traces, since these showed close resistance without $\mathrm{CBC}$. One way to better study this behavior may be to perform new traits with intermediate levels between $5 \%$ and $25 \%$.

According to Fioritti (2007) [17], the compressive strength of $15 \mathrm{MPa}$ is satisfactory, since public walking requests are lower than this value. The author also proposes that the values required in the Brazilian standards should be reduced considering the application of the material. In this context, all the traits presented a resistance close to the one suggested by the author, and can be applied in places with smaller requests than the public roads contemplated in NBR 9781: 2013 (ABNT, 2013) ${ }^{[18]}$, as for example, and bike paths After the analysis of the results, the trait considered as the optimal substitution content is the T5 trait, in which $27 \%$ of sand was replaced by residues $(25 \%$ by $\mathrm{CBC}$ and $2 \%$ by Tire). This trait reached a resistance of $32.22 \mathrm{MPa}$, only $5 \%$ lower than the reference trace (T0), showing that it is feasible to replace the aggregate with the proposed residues.

\subsubsection{WATER ABSORPTION}

The water absorption of the pavers was determined by the methodology established in NBR 9781: 2013 (ABNT, 2013) [18] and following the methodology described in Annex $B$, for the age of 28 days. The results obtained in the tests are shown in Table 13.

The results of the tests are represented graphically in Figure 17. In all the traces made this index was below the maximum allowed by NBR 9781: 2013 (ABNT, 2013) [18] which is 6\%.

The water absorption for the traces made with $\mathrm{BCC}$ was lower than that obtained in the reference trait. Furthermore, the absorption index decreases with the increase in the kid content of CBC. This fact can be explained by the low porosity that the pavers made with this residue presented. As the CBC is extremely thin it fills the voids between the other aggregates, reducing the porosity and, consequently, the water absorption.

\section{Table 13}

\section{Water absorption index}

\begin{tabular}{ccc}
\hline \multicolumn{2}{c}{ Trace } & $\begin{array}{c}\text { Water absorption } \\
(\%)\end{array}$ \\
\hline T0 & - & 5,54 \\
T1 & $25 \%$ CBC & 3,60 \\
T2 & $5 \%$ CBC & 4,71 \\
T3 & $5 \%$ tire & 5,95 \\
T4 & $2 \%$ tire & 5,19 \\
T5 & $25 \%$ CBC 2\% tire & 5,23 \\
T6 & $5 \%$ CBC 2\% tire & 5,59 \\
T7 & $25 \%$ CBC 5\% tire & 5,00 \\
T8 & $5 \%$ CBC 5\% tire & 4,86 \\
\hline
\end{tabular}

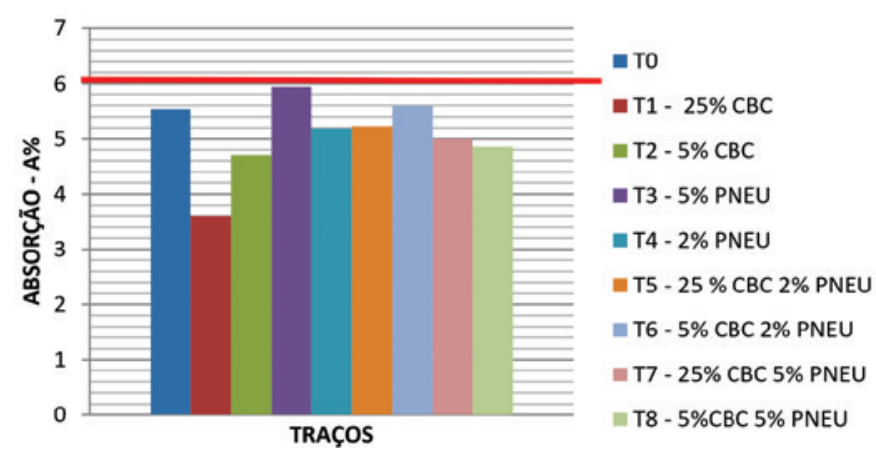

Figure 17

Absorption chart 
The same does not occur with pavers manufactured with waste tires, which indicates that these parts have a higher porosity, although it is within the parameters required by the standard. However, when $\mathrm{CBC}$ is added to the mix, these indices are reduced, which shows that the $\mathrm{CBC}$ contributes to improve this characteristic of the pavers as well.

\subsubsection{ABRASION}

The abrasion resistance test was performed only for the reference trait and the trait that presented the best result in the mechanical property, the T5 trait, and one specimen was used for each trait. From each sample two samples were taken, the pavers made with Trace T0 presented a wear of $6.29 \mathrm{~mm}$ and those fabricated with the $T 5$ trace $6.37 \mathrm{~mm}$.

The results obtained are relatively high when compared to the results of other tests. This is due to the fact that the Cientec Method is considered as the most abrasive test because it uses the silicon carbide, which wears all the mineral material that makes up the concrete.

However, the authors suggest that wear should be limited to 15 $\mathrm{mm}$, which is the mean value reached by several authors (Hood, 2006) ${ }^{[24]}$. In the case of NBR 9781: 2013 (ABNT, 2013) ${ }^{[18]}$ the maximum permissible wear is $23 \mathrm{~mm}$ for pavers subject to pedestrian traffic, light vehicles and commercial vehicles

The result obtained for the reference trait is compatible with the results found by other researchers who used the Cientec Method for the analysis of abrasion resistance. Amadei (2011) ${ }^{[19]}$ analyzed this feature in his research and obtained a wear of $6.40 \mathrm{~mm}$ in his reference stroke and Hood (2006) reached $6.17 \mathrm{~mm}$.

Regarding the paver fabricated with $\mathrm{CBC}$ and Tire the results presented do not demonstrate that the substitution influenced this characteristic, once again showing the viability of the substitution.

\section{Conclusions}

The feasibility of the use of the residues was analyzed according to tests of resistance to compression, water absorption and resistance to abrasion, thus evaluating the mechanical and durability characteristics of the pieces.

As the proposal is the joint use of waste the analysis of the results was focused on the pieces made with $\mathrm{CBC}$ and waste tires, however, we can not fail to comment the results obtained with the use of the same. In the case of CBC there was a significant improvement of the properties analyzed, which was already expected based on previous research. On the other hand, the residuals of tires presented negative results for the manufacture of pavers. Even when used in small quantities, the reduction of mechanical resistance and the increase of water absorption can be observed. However, when used together there is a kind of compensatory effect, which makes it possible to use them.

Based on the results of the tests carried out, Trace T05 was chosen as the optimum content, that is, the one that presented the least influence of the substitution of the aggregate by residues in the analyzed characteristics, even using maximum possible substitution levels, $25 \%$ CBC and $2 \%$ of tire, totaling $27 \%$. Trace T05 was the closest to the reference trait in terms of strength, water absorption and abrasion resistance.
The improved characteristics of pavers made with $\mathrm{CBC}$ tire residue can be explained by the filler effect of $\mathrm{CBC}$ in concretes, involving better particles and reducing voids between pulp and aggregates. In addition, although it does not have a significant reactivity that classifies it as pozzolana, CBC even when burned at high temperatures contributes in a decisive way to the increase of mechanical resistance. It should be noted that both the results presented and the conclusions drawn from them are based on local materials, equipment, techniques and conditions.

From the environmental point of view, the use of these wastes contributes to the reduction of the extraction of natural resources and also promotes their adequate disposal.

\section{Thanks}

The Federal Technological University of Paraná.

The State University of Maringá, the Campus City Hall, the collaborators of the Cement Artifacts Factory and the Construction Materials Laboratory.

To Sika Brasil S.A; Usina Santa Terezinha, Rubber SS.

\section{Referências bibliográficas}

[1] ROSA, P. A. O. Produção Mais Limpa. Tecnologias Limpas. In: FÓRUM INTERNACIONAL DE RESÍDUOS SÓLIDOS, 1., 2007, Porto Alegre. Online... Porto Alegre, 2007. Disponível em: http://www.institutoventuri.com.br/img_f orum/palestras/Palestras $\% 20-\% 2019 \% 20$ de $\% 20$ maio $\% 20$ 20Manh_Paulo\%20Rosa.pdf. Acesso em: 13 Jun. 2016.

[2] JOHN, V. M. Reciclagem de resíduos na construção civil: Contribuição para metodologia de pesquisa e desenvolvimento. 2000. 113 f. Tese (Livre Docência) - Escola Politécnica da Universidade de São Paulo, Departamento de Engenharia de Construção Civil, São Paulo, 2000.

[3] BRASIL. Lei Federal n 12.305, de 02 de agosto de 2010. Institui a Política Nacional de Resíduos Sólidos. Diário Oficial da União, Brasília, DF, 03 de Ago. 2010. Disponível em: <http://www.planalto.gov.br/ccivil_03/_ato2007-2010/2010/ lei/l12305.htm>. Acesso em: 27 Jun. 2016.

[4] ASSOCIAÇÃO NACIONAL DA INDÚSTRIA PNEUMÁTICA ANIP. O livro Branco da Industria de Pneus. 2016. Disponível em: http://www.anip.com.br/index.php?cont=conteudo. Acesso em: 23 maio. 2016.

[5] CONAB - COMPANHIA NACIONAL DE ABASTECIMENTO. Acompanhamento da safra brasileira de Cana-de-Açúcar 2016/2017 - Segundo Levantamento. 2016. http://www.conab.gov.br/OlalaCMS/uploads/arquivos/16_04_18_14_27_15_boletim_cana_portugues_-_10_ lev__-16.pdf. Acesso em: 16 Jul. 2016.

[6] ALTOÉ, S. P. S. Estudo da potencialidade da utilização de cinza de bagaço de cana-de-açúcar e resíduos de pneus inservíveis na confecção blocos de concreto para pavimentação. 179f. Dissertação (Mestrado em Engenharia Urbana) - UEM. Maringá. 2013.

[7] ABCP- Associação Brasileira de Cimento Portland, 2002. Guia básico de utilização do cimento Portland - BT-106; 7 ed. São Paulo: ABCP, 28 p. 
[8] ASSOCIAÇÃO BRASILEIRA DE NORMAS TÉCNICAS. NBR NM 248. Agregados - Determinação da composição granulométrica. Rio de Janeiro, 2003.

[9] ASSOCIAÇÃO BRASILEIRA DE NORMAS TÉCNICAS. NBR NM 45. Agregados - Determinação da massa unitária e do volume de vazios, 2006.

[10] ASSOCIAÇÃO BRASILEIRA DE NORMAS TÉCNICAS. NBR NM 53. Agregado graúdo - determinação de massa específica, massa específica aparente e absorção de água. Rio de Janeiro, 2003.

[11] ASSOCIAÇÃO BRASILEIRA DE NORMAS TÉCNICAS. NBR NM 52. Agregado miúdo - Determinação de massa específica e massa específica aparente. Rio de Janeiro, 2003.

[12] ASSOCIAÇÃO BRASILEIRA DE NORMAS TÉCNICAS. NBR 15895: Materiais pozolânicos - Determinação do teor de hidróxido de cálcio fixado - Método Chapelle modificado. Rio de Janeiro, 2010.

[13] ASSOCIAÇÃO BRASILEIRA DE NORMAS TÉCNICAS. NBR 7181: Solo - análise granulométrica. Rio de Janeiro, 1984.

[14] ASSOCIAÇÃO BRASILEIRA DE NORMAS TÉCNICAS. NBR 6508: Massa específica dos Sólidos. Rio de Janeiro, 1984.

[15] ASSOCIAÇÃO BRASILEIRA DE NORMAS TÉCNICAS. NBR 10005: Procedimento para obtenção de extrato lixiviado de resíduos sólidos. Rio de Janeiro, 2004.

[16] ASSOCIAÇÃO BRASILEIRA DE NORMAS TÉCNICAS. NBR 10006: Procedimento para obtenção de extrato solubilizado de resíduos sólidos Rio de Janeiro, 2004.

[17] ASSOCIAÇÃO BRASILEIRA DE NORMAS TÉCNICAS. NBR 10004 Resíduos Sólidos - Classificação. Rio de Janeiro, 2004.

[18] ASSOCIAÇÃO BRASILEIRA DE NORMAS TÉCNICAS. NBR 9781. Peças de concreto para pavimentação- Especificação e métodos de ensaio. Rio de Janeiro, 2013.

[19] AMADEI, I. B. A. Avaliação de blocos de concreto para pavimentação produzidos com resíduos de construção e demolição do Município de Juranda/PR. 153 f. 2011. Dissertação (Mestrado) - Universidade Estadual de Maringá, Programa de Pós-Graduação em Engenharia Urbana, Maringá, 2011.

[20] FERNANDES, I. D. Blocos \& Pavers: Produção e Controle de Qualidade. 3. ed. Jaraguá do Sul: Treino Assessoria e Treinamentos Empresariais Ltda., 2012a. 182 p. ISBN 978.85.62290-01-5.

[21] NEVILLE. A. M. Properties of concrete. 4 edition, London, Longman, 1995, 844p.

[22] FIORITI, C. F. Pavimentos intertravados de concreto utilizando resíduos de pneu como material alternativo. $202 \mathrm{f}$. Tese (Doutorado) - Escola de Engenharia da Universidade de São Paulo, São Carlos, 2007.

[23] MASKI - PRÉ-FABRICADOS. Assentamento do pavimento intertravado Práticas recomendadas. 2011. Disponível em: <http://www.maski.com.br/prefabricados/assentamento-dopavimento-intertravado>. Acessado em: 12 Jan. 2012.

[24] HOOD, R. S. S. Análise da viabilidade técnica da utilização de resíduos de construção e demolição como agregado miúdo reciclado na confecção de blocos de concreto para pavimentação. 2006. 150 p. Dissertação (Mestrado) - Universidade Federal do Rio Grande do Sul, Porto Alegre, 2006.
[25] INSTITUTO DE PESQUISA E TECNOLOGIA DE SÃO PAULO - Procedimento IPT123-CT-OBRAS-LMCC-Q-PE041 Revisão 01. 